\title{
Leveraging funds for school infrastructure: The South African 'mud schools' case study
}

\author{
Ann Skelton* \\ University of Pretoria, South Africa
}

Keywords:

Infrastructure

Justiciability

Litigation

Budgeting

Monitoring

Post-2015

\begin{abstract}
A B S T R A C T
In 2013 there are still thousands of children in South Africa attending dilapidated mud schools, schools lacking sanitation, and schools without electricity. The situation took a positive turn in 2009 when the government was taken to court about the severe infrastructure backlogs in the Eastern Cape province. The case settled out of court, and resulted in a memorandum of agreement which pledged $\mathrm{R} 8.2$ billion over three years. However, the allocation of these and other funds has not immediately translated into tangible results on a broad scale. This is because large infrastructure projects require management capacity that is lacking in Department of Education in South Africa. This paper demonstrates the justiciability of the right to education, and shows that litigation, implementation monitoring and budgetary analysis may be new tools to lever funds for education at the country level, and to hold government accountable for efficient spending. The significance of this to the post-2015 development context is that developing countries must find new methods for ensuring the provision and expenditure of funds from existing budgets within their own countries. In order to achieve this education activists must forge new alliances with partners who have knowledge in budgeting, budgetary analysis and where necessary, litigation.
\end{abstract}

\section{Introduction}

Centre for Child Law and Seven Others $v$ Government of the Eastern Cape Province and Others, is often referred to as the 'mud schools' case. ${ }^{1}$ Seven schools (amongst others) had battled for almost a decade to get any attention from the provincial department about their severe infrastructure problems. The complaints included firstly, dilapidated mud buildings (in some cases roofs missing and classes being held in neighbourhood dwellings), secondly, no running water or sanitation and thirdly inadequate seats and desks for the number of learners attending the schools. The Legal Resources Centre, on behalf of the Applicants, launched an application in the Grahamstown High Court during 2010. The matter settled out of court, resulting in a far - reaching 'memorandum of understanding' signed on 4 February 2011 which pledged a total of $\mathrm{R} 8.2$ billion over a three year period and specific amounts earmarked for the seven schools. The agreement

\footnotetext{
* Tel.: +27 124204502; fax: +27 124204499.

E-mail address: ann.skelton@up.ac.za

1 Centre for Child Law and 7 others $v$ Government of the Eastern Cape Province and others, Eastern Cape High Court, Bhisho, case no 504/10.
}

included the development of a plan for infrastructure to be managed by the National Department of Basic Education, undertakings about interim arrangements such as prefabricated buildings and the installation of water tanks. An important term of the agreement provides that if there should be a serious breach of the agreement, the parties can, giving two weeks' notice, go back to court to force compliance.

The fact that education is a human right is certainly not new. As a means of measuring compliance with the right, Katarina Tomasevski, the UN Special Rapporteur on the Right to Education from 1998 to 2004, developed what is commonly referred to as the "4 A" scheme, incorporating availability, accessibility, acceptability and adaptability. The UN Committee on Social, Economic and Cultural Rights adopted in their General Comment on the Right to Education (General Comment 13), issued in 1999. The scheme forms a useful benchmark against which to measure governments' performance towards the realisation of the right to education, because it embodies international law principles (Beiter, 2006). This article proposes that litigation on children's right to education, provided that it is followed by proper monitoring of outcomes, can be used to promote another important " $\mathrm{A}$ "-word: Accountability. In his report on the right to education submitted to the 68th session of the General Assembly, the Special Rapporteur, Kishore 
Singh, recommended that "accountability should be a cornerstone of the post-2015 development agenda, with the emphasis on mechanisms to hold governments accountable to their commitments" (Report of the Special Rapporteur, August 2013, para 126).

Although 'education for all' is premised on human rights, mechanisms for making the right real have been insufficiently explored. The UN Special Rapporteur on the right to education, Kishore Singh, presented a report to the 23rd session of the Human Rights Council on 10 May 2013, entitled "Justiciability of the right to education". The report identifies justiciability of the right to education as a key instrument for its realisation. In other words, government policies and provisions of education are subject to review and determination by judicial and quasi-judicial bodies. Adjudication of the right to education by such bodies ensures that the right to education is respected, protected and fulfilled (Report of the Special Rapporteur, May 2013, part III).

This case study on mud schools presents a South African example of how government has been held accountable for the failure to provide a proper educational environment for children. As will be demonstrated, the case leveraged funding to deal with infrastructure backogs. The article also shows that litigation on its own may not be sufficient to ensure full accountability. Monitoring of expenditure following the out of court settlement indicates slow progress and further litigation may be necessary. The case study charts a role for civil society in the post 2015 development agenda. The Special Rapporteur has recommended that 'rights-holders should have the ability to challenge governments to meet their international obligations when they are not be respected and fulfilled. Access to justice is of foremost importance for getting the rights enforced' (Report of the Special Rapporteur, August 2013, para 129). He concludes that effective enforcement mechanisms linked to government accountability should be foreseen in the in the future agenda (para 130).

\section{What is a 'mud' school?}

Mud schools are, quite literally, schools in which the buildings are made of mud. They may consist of clusters of round mud huts, or in some cases are rectangular classrooms. While mud may not be the worst form of building material, the problem is that the mud schools are old and dilapidated. The roofs, often constructed from corrugated iron, have holes that have rusted through, causing children and classroom equipment to get wet when it rains. Books cannot be left in the classrooms, and when it rains, children simply cannot attend school. Mud schools also lack electricity, running water and sanitation, and most have old and insufficient classroom furniture. The government has indicated that there are 510 of these schools, the vast majority of which are in the Eastern Cape Province (Department of Basic Education, 2013). These 'inappropriate structures' as the government refers to them, are the left overs of a deliberate strategy during the apartheid years not to invest in schools for black children.

It is not a coincidence that the Eastern Cape, which has the most acute school infrastructure backlog, was an area which, during the apartheid regime's rule, contained two 'homelands' or 'Bantustans'. These were delineated by the apartheid powers as part of its separate development policy which aimed to ensure that all black South Africans belonged to their 'own areas' which, in the warped political imagination of apartheid's architects, were not part of South Africa. In this manner, the government aimed to render white South Africans a majority in South Africa, while the far bigger population of black South Africans were deemed to live in other countries. The grand plan failed, but its legacy of impoverishment and under-development in the former 'homelands' lives on.
While this history is pertinent, a reasonable observer might expect that almost two decades after the end of apartheid the worst of the infrastructure deficits would have been eradicated. Indeed, the National Department of Education issued National Norms and Standards for School Funding in October 1998, which it committed itself to eliminating school backlogs. In his State of the Nation address in 2004, President Thabo Mbeki assured the country that, by the end of that year, no learner would still be learning under a tree or in a mud school. The National Department of Basic Education has a more recent policy that requires schools to be maintained in a condition that makes teaching and learning possible (Department of Basic Education, 2010), and yet so many schools remain in a parlous condition. It is true that the problem is a daunting one. The National Department of Education has identified the following needs: There are 510 inappropriate structures, 2401 schools that have no water on site, 3544 that have no electricity, and 913 that have no ablution facilities (Parliamentary Monitoring Group, 2012).

\section{Does infrastructure matter?}

Spaull has identified two binding constraints on quality outputs in South African basic education - namely teacher absenteeism and teacher content knowledge (2013b). These findings are in keeping with wide-ranging research which shows that the issues most closely related to teachers that have the greatest impact on learning outcomes (Mason, 2013). Thus it is theoretically possible for an excellent teacher to garner good results from learners in a mud school environment. However, it must be remembered that extremely poor infrastructure has an effect on teachers, as well as pupils. A school which has no toilets for learners will usually have no toilets for teachers either. If children get wet when the roof leaks, so might teachers. A second reason why good quality outputs are unlikely from mud schools is that children who learn in mud schools with no electricity, no running water and no toilets are likely to live in circumstances that are similarly bereft of services. These circumstances are generally significant in learner outcomes (Van den Berg, 2008). Finally, this is also a socio-economic rights issue. If the Post-2015 Development Agenda requires that no one is left behind, the inequality between the learning environment offered by mud schools and other public schools in South Africa is simply unacceptable (Spaull, 2013a). Accountability is also identified as a crucial element of that Agenda (High-Level Panel of Eminent Persons, 2013; Report of the Special Rapporteur, August 2013).

\section{Litigation to ensure accountability in relation to education}

One way to achieve accountability is through public interest litigation. The special rapporteur, in his report on the justiciability of the right to education, sets out international examples of jurisprudence arising from education related court cases on equality of opportunity, protection of marginalised and vulnerable groups, quality, minority and language rights, girls rights, the financing of education and the regulation of private education provision (Report of the Special Rapporteur, May 2013, part VIII). Litigation of the right to education has a history in developed countries (Welner, 2012), but is relatively new in developing countries (Byrne, 2013).

South Africa has a history of public interest litigation in a range of human rights violations. This form of activism dates back to the Apartheid era during which organisations such as Legal Resources Centres and Lawyers for Human Rights brought cases before the courts, using rule of law arguments to chip away at the edifice of the apartheid legal system, particularly in relation civil and political rights (Marcus and Budlender, 2008). It has, however, 
also been a strategy used during the post-1994 Constitutional era to hold the new government accountable on a range of rights issues, including socio economic rights.

The Bill of Rights in the South African Constitution contains justiciable rights. This means that when government fails to deliver on the promises made in the Constitution, it can be taken to court. This includes socio-economic rights, such as education. South Africa is a constitutional democracy, with a separation of powers and an independent judiciary $<$ !-(Skelton, 2012). Citizens living in countries that have such a constitutional and political order are well placed to undertake litigation as a means to enforce rights.

Section 29(1)(a) of the Bill of Rights states that everyone 'has the right to a basic education'. The Constitutional Court has explained the significance of this wording in the recent case of The Governing Body of the Juma Musjid Primary School and another $v$ Essay NO and Others (Centre for Child Law and Another as Amici (uriae) $)^{2}$ :

"It is important, for the purposes of this judgment, to understand the nature of the right to 'a basic education' under section 29(1)(a). Unlike some of the other socio-economic rights this right is immediately realisable. There is no internal limitation requiring that the right be 'progressively realised' within 'available resources' subject to 'reasonable legislative measures'. The right to a basic education in section 29(1)(a) may be limited only in terms of a law of general application which is 'reasonable and justifiable in an open and democratic society based on human dignity, equality and freedom'. This right is therefore distinct from the right to 'further education' provided for in section 29(1)(b). The state is, in terms of that right, obliged, through reasonable measures, to make further education "progressively available and accessible" (para 37).

This means, in essence, that the government must provide basic education to all children without delay. Lack of planning, inability to carry out plans and lack of resources are not, legally speaking, permissible defences to the violation of a child's right to a basic education.

Given this extraordinary promise it is surprising that it took rather a long time for public interest litigation that directly tackles the right to a basic education to emerge. The Constitutional Court first dealt with the right to a basic education in Ex parte Gauteng Provincial Legislature: In re dispute concerning the constitutionality of certain provisions of the Gauteng School Education Bill of 1995. ${ }^{3}$ The court held that the right was more than a negative right requiring government not to impede, it in fact created positive obligations on the state to ensure that the right can be achieved by all. This jurisprudence was expanded upon in the Juma Musjid case, which established that the right is immediately realisable, as, unlike other socio-economic rights, it is not subject to progressive realisation.

There has been a steadily increasing stream of cases concerning the right to a basic education (Skelton, 2013). Several have dealt with infrastructure, ${ }^{4}$ some with the provision of learning materials ${ }^{5}$ and some with the availability of teachers and non-teaching

\footnotetext{
20117 BCLR 651 (CC), hereafter 'Juma Musjid'.

31996 (3) SA 165 (CC).

${ }^{4}$ Equal Education and others v Minister for Basic Education and others, Bhisho High Court.

${ }^{5}$ Freedom Stationery (Pty) Ltd v MEC for Education Eastern Cape (Unreported (59/2011) [2011] ZAECBHC1 (2010-03-10)); Section $27 \mathrm{v}$ Minister of Education 2013 (3) SA 40 (GNP); Basic Education for All v Minister of Basic Education 2014 (4) SA 274 (GP).

${ }^{6}$ Centre for Child Law v Minister of Basic Education Eastern Cape [2012] 4 All SA 35 (ECG).

7 Governing Body of Rivonia Primary School v MEC for Education: Gauten Province [2012] 1 All SA 576 (GSJ); Governing Body, Rivonia Primary School v MEC for Education, Gauteng Province 2013 (1) SA 632 (SCA).
}

personnel. ${ }^{6}$ Others have dealt with admissions policy ${ }^{7}$ and language policy, ${ }^{8}$ and access to education for children with special needs. ${ }^{9}$ Yet others concern children's rights within education such as the right to be protected from corporal punishment, ${ }^{10}$ to express religious beliefs ${ }^{11}$ and fair pregnancy policy. ${ }^{12}$

One of these cases, which did not get as far as to being argued in court, was the mud schools case. It began with a letter of demand from the Centre for Child Law on behalf of seven schools and all other schools similarly situated. The letter was ignored. The Legal Resources Centre, acting for the Centre and the seven schools, then served papers on the department. These included a lengthy affidavit which set out the miserable state of affairs in the schools, and a notice of motion setting out the action that needed to be taken. The Department initially filed an opposing affidavit, but later reconsidered and made an offer to settle. Following the signing of the agreement, the national Department of Basic Education issued the 'Accelerated schools infrastructure delivery initiative' (ASIDI), as its implementation plan to deal with the infrastructure backlog. This set out the list of schools requiring infrastructure upgrades, and identified 496 schools with inappropriate structures. The Department has since revised this figure: in April 2013 it is recorded as 510 schools (Department of Basic Education, 2013).

While the mud schools case was hailed as a victory, the real test of this strategy rests on whether the schools actually get built within the required time frames. Thus monitoring of the processes of budgeting, spending, procurement and construction became the next important phase in the eradication of mud schools.

\section{Monitoring compliance}

The litigation phase had been undertaken by lawyers, working together with 'infrastructure crisis committees' of each of the seven schools, made up of parents and teachers. The monitoring phase required new and different skills. The Legal Resources Centre employed a consultant with construction experience to monitor progress in the construction of the first seven schools.

The Centre for Child Law commissioned a study by Cornerstone Economic Research, to track school infrastructure spending and delivery (Abdoll and Barberton, 2013). The report reveals poor delivery in terms of school infrastructure backlogs, with only four of the schools having been completed in the first year $(2011 / 12)$ and 12 in the second year $(2012 / 13)$. The researchers determine that a lack of money is not the problem. Firstly, they point out that South Africa's total public expenditure on educational institutions and administration amounted to 5.9\% of the GDP, which is slightly above the OECD average of $5.4 \%$.

Secondly, the original amount of 8.2 billion leveraged by the mud schools case has in fact been added to by the government, and amounts to a total of 13 billion over the 2012 medium term expenditure framework of three years. This is also not the only money being spent on infrastructure. The $\mathrm{R} 13$ billion allocated for school infrastructure backlogs is a conditional grant, which is held and administered at a national level. This is the money earmarked for the mud schools refurbishment. In addition, the provincial

\footnotetext{
${ }^{8}$ Mikro Primary School 2006 (1) SA 1 (SCA); Head of Department, Mpumulanga Department of Education v Hoerskool Ermelo 2012 (2) SA 415 (CC).

9 Western Cape Forum for Intellectual Disability v Government of the Republic of South Africa 2011 (5) SA 87 (WCC).

${ }^{10}$ Christian Education SA v Minister of Education 2000 (4) SA 757 (CC).

11 MEC for Education, Kwa Zulu Natal v Pillay 2008 (1) SA 474 (CC); Antonie v Governing Body, Settlers High School and Others 2002 (4) SA 738 (C).

12 Welkom High School v Head, Department of Education, Free State Province 2011 (4) SA 531 (FB); Head, Department of Education, Free State Province v Welkom High School 2012 (6) SA 525 SCA; Head of Department of Education, Free State Provice v Welkom High School CCT 103/12 [2-13] ZACC 25 (10 July 2013).
} 
departments also have budgets for infrastructure which are being spent, on average, more efficiently that the monies held by the national department (with the exception of the Eastern Cape where the majority of mud schools are situated). Overall, however, the report finds that the availability of funds did not play a role in the poor rates of completion. The funds were available but were not spent.

The report states that due to the absence of norms and standards on infrastructure, as well as a lack of reliable information on existing infrastructure available in the public domain it is not possible to create a precise picture of the infrastructure backlog. Indeed, the Department of Basic Education itself appears to be unsure how many 'inappropriate structures' there are, as it has provided different numbers in different reports ranging from 395 to the most recent figure of 510 . This calls their strategic planning into question.

The report makes the concerning finding that the national Department of Basic Education has woefully underspent the School Infrastructure Backlog grant for two years running. In $2011 / 2012$ spending was a little over $10 \%$ and only at 23 per cent in 2012/2013 at the end of the third quarter. The ASIDI target for the number of schools to be built in 2011/2012 and $2012 / 2013$ was 49 . However, only 10 had been completed by the end of the first year. The Department identifies the following reasons for their failure: Inclement weather, the rural nature of the sites and poor roads, recruitment of contractors has to be done according to rigid procurement procedures, problems with contractors, profiteering and shortages of building materials (Department of Basic Education, 2013). Abdoll and Barberton find that the reason for the National Department's underspending is poor capacity within the Department to plan and manage an infrastructure programme of this size.

The authors conclude that, at the current delivery rates, the realistic time frame for the eradication of schools with inappropriate structures will probably 2023 or 2024 . This will be grave disappointment to the many children in mud schools who have been waiting so long for decent classrooms and schools. However, the authors propose that this could change if pressure is brought to bear on the Department of Basic Education to structure contracts differently, to attract big construction companies to either do the work directly or sub-contract it. Penalty clauses for non-delivery should be introduced.

\section{Observations about the efficacy of litigation to achieve education rights}

There are debates about the efficacy of litigation as a means to achieving socio-economic rights, including the right to education (Rosenberg, 2008; Tushnet, 2008; Nolan, 2011). One of the concerns relates to the courts' incapacity to assess how much money the executive should allocate to what services. The courts are reluctant to wade in and make orders that bind the state in situations where polycentric issues are at stake, as the court may not be fully appraised of all the competing demands on the public purse. However, Nolan (2011) has pointed out that courts, like other institutions, can be educated through information placed before them by public interest litigators such as 'friends of the court'. Some Latin American superior courts have used a consultative approach by holding 'public hearings' to obtain additional information. Liebenberg (2010) has observed a similar trend towards a dialogic approach in South Africa. Of course, the fact that the mud schools case settled out of court meant that the problem of asking the court to make a far-reaching order was obviated.

There are other concerns about what will happen if governments refuse or simply fail to carry out court orders. In some legal systems courts can craft supervisory orders which gives them the power to oversee the implementation of their orders (Roach and Budlender, 2005). However, there needs to be a broader accountability process, in which civil society monitors compliance.

A further concern about such litigation relates to questions about its place in the bigger space of social movements to bring about basic education for all children. There is a risk that if the 'struggle' for the right to education is spearheaded by professionals such as lawyers and economists, there will be insufficient engagement in the battles by the actual rights holders themselves - such as children and parents. The early education law cases in South African have demonstrated this trend of being led by nongovernmental organisations, but there is current work being done by organisations such as Equal Education and Section 27 to build more broad-based social movements for education. Veriava (2012) has pointed out that litigation strategists and social movements can be mutually supportive, with successful cases leading to heightened awareness of rights, and renewed energy amongst rights holders to take forward their campaigns.

\section{Conclusion}

The post 2015 Agenda is premised on the reality that there will be less financial aid to developing countries in the future. The story of the mud schools paints a picture that clearly resonates with a post-2015 approach. Until now, describing education as a human right has been a mantra uttered by many, but enforced by few, particularly in developing countries. It is now necessary to ensure that the right to a basic education is a justiciable right, and that governments failing to provide adequate quality education to all their citizens must be held accountable. Litigation can be an effective instrument in this challenge.

If no children are to be left behind, then developing countries must find the means to provide equal opportunities for all children to learn in a decent environment. Parent bodies, education advocates and activists must seek new partners and learn new skills to hold governments accountable, and ensure that deliver on their obligations regarding the right to education. These new partners may include lawyers and economists, procurement experts, infrastructure planners and construction experts. Public private partnerships may need to be explored.

The mud schools case leveraged a large sum of money to clear the infrastructure backlogs. However, the allocation of funds has proved to be only one factor pertinent to the success of the endeavour. Large sums of money will not reach the poorest children in the poorest schools timeously unless the capacity to plan and manage large infrastructure projects is developed. A new approach must ensure a robust monitoring of planning, budgeting and spending. There must be a demand for adequate financial information to be placed in the public domain to allow for such scrutiny.

If we are to re-vision the post 2015 agenda, it should be done in a manner that encourages organisations, parent bodies and even learners themselves to hold governments accountable. This requires not only making demands on the public purse to ensure that more money is allocated to education, but also ensuring that, once allocated, it is efficiently spent.

\section{References}

Abdoll, C., Barberton, C., 2013. School infrastructure spending and delivery. Cornerstone Economics, commissioned by Centre for Child Law.

Beiter, K., 2006. The Protection by International Law of the Right to Education Martinus Nijhoff Publishers, Leiden.

Byrne, I., 2013. Litigating the right to universal primary education: challenges and prospects. Interights Bulletin 17 (2), 56.

Department of Basic Education, February 2013. ASIDI Brief 1. 
Department of Basic Education, 2010. National Policy for an Equitable Provision of an Enabling School Physical Teaching and Learning Environment. Department of Basic Education, Pretoria.

High-Level Panel of Eminent Persons on the Post-2015 Development Agenda, 2013 A New Global Partnership: Eradicate Poverty and Transform Economies through Sustainable Development.

Liebenberg, S., 2010. Socio-Economic Rights: Adjudication Under a Transformative Constitution. Juta, Cape Town.

Marcus, G., Budlender, S., 2008. A Strategic Evaluation of Public Interest Litigation in South Africa: a Strategic Evaluation. Atlantic Philanthropies, Johannesburg.

Mason, M., 2013. Educational development agendas post-2015, and a continuing focus on Africa. International Journal of Educational Development 33, 407.

Nolan, A., 2011. Children's Socio-Economic Rights, Democracy and the Courts. Hart Publishing, Oxford

National Department of Education, 1998. National Norms and Standards for School Funding.

Department of Basic Education Presentation.

Report of the Special Rapporteur on the right to education, Kishore Singh, May 2013 Justiciability of the right to education. A/HRC/23/35.

Report of the Special Rapporteur on the right to education, August 2013. The right to education. A/68/294.

Roach, K., Budlender, G., 2005. Mandatory relief and supervisory jurisdiction: when is it appropriate, just and equitable? South African Law Journal 22, 325-350.
Rosenberg, G., 2008. 2nd ed. The Hollow Hope: Can Courts Bring About Social Justice? University of Chicago Press, Chicago.

Skelton, A., 2012. How far will the courts go in ensuring the right to a basic education? South African Public Law 27, 392-408.

Skelton, A., 2013. The role of the courts in ensuring the right to a basic education in a democratic South Africa: a critical evaluation of recent education case law. De Jure 1, 1-23.

Spaull, N., 2013a. Poverty and privilege: primary school inequality in South Africa. International Journal of Educational Development 33, 436-447.

Spaull, N., 2013b. South Africa's Education Crisis: The Quality of Education in South Africa 1994-2011. Stellenbosch University, Stellenbosch.

Tushnet, M., 2008. Weak Courts, Strong Rights: Judicial Review and Socia Welfare Rights in Comparative Constitutional Law. Princeton University Press, Princeton.

United Nations Committee on Economic, Social and Cultural Rights, 1999. General Comment 13.

Van den Berg, S., 2008. How effective are poor schools? Poverty and educational outcomes. Studies in Educational Evaluation 34, 145-154.

Veriava, F., 2012. Court Cases Initiate Domino Effect, Newspaper. Article available from http://mg.co.za/article/2012-08.31-court-cases-initiate-domino-effect (accessed 28.06.14).

Welner, K., 2012. Scholars as policy actors: research, public discourse, and the zone of judicial constraints. American Educational Research Journal 49 (1), 7-29. 